P R E F A C E

\title{
Introduction: from snowball Earth to the Cambrian explosion-evidence from China
}

\author{
MAOYAN ZHU* $+\dagger \&$ XIAN-HUA LI $\$ \S \dagger$ \\ * State Key Laboratory of Palaeobiology and Stratigraphy, Nanjing Institute of Geology and Palaeontology, Chinese \\ Academy of Sciences, Nanjing 210008, China \\ †College of Earth Sciences, University of Chinese Academy of Sciences, Beijing 100049, China \\ $\S$ State Key Laboratory of Lithospheric Evolution, Institute of Geology and Geophysics, Chinese Academy of Sciences, \\ Beijing 100029, China
}

The Neoproterozoic-Palaeozoic transition (NPT) around $600 \mathrm{Ma}$ ago was a critical time interval when the Earth experienced fundamental change, manifested as climatic extremes - 'snowball Earth' - followed by the emergence and rapid diversification of animals - 'Cambrian explosion'. How animals and environments co-evolved, and what caused these fundamental changes to the Earth system during the NPT, is a great scientific puzzle, which has been a rapidly developing frontier of interdisciplinary research between bio- and geosciences. South China preserves a complete stratigraphic succession of the NPT developed in various facies ranging from shallow to deep marine realms with extraordinarily well-preserved, successive fossil biotas in various taphonomic settings (Zhu, 2010; Fig. 1), making it a key area and global focus of studies in the field over recent decades. Indeed, the current narrative of early animal evolution has largely been based on the fossil biotas from South China. These include: (1) the world's oldest microscopic animal fossils with cellular details from the early Ediacaran Weng'an biota (Doushantuo Formation); (2) putative macroscopic animal fossils preserved as carbonaceous imprints from the early Ediacaran Lantian, Wenghui and Miaohe biotas (also Doushantuo Formation); (3) typical late Ediacaran faunas, preserved in dark limestone (Shibantan biota) and as large and poorly mineralized tubular animal fossils (Gaojiashan biota), both from the Dengying Formation; (4) phosphatized small shelly and soft-bodied animal fossils from the early Cambrian Meishucun and Kuanchuanpu faunas; and (5) Cambrian fossil Lagerstätten (Chengjiang, Guanshan and Kaili faunas) with typical Burgess Shale-type soft-bodied preservation.

In addition to their unique archives of early animal evolution, lithologically the composite stratigraphic successions of South China provide the potential to apply various sedimentary geochemical proxies for documenting environmental changes. For example, fre-

†Authors for correspondence: myzhu@nigpas.ac.cn \& lixh@gig. ac.cn quent and dramatic carbon isotope perturbations and ocean redox evolution, evidenced from South China successions, have been suggested to reflect global changes in seawater chemistry that may have been closely related to contemporaneous biological evolutionary events (e.g. Zhu et al. 2007; Li et al. 2010; Sahoo et al. 2012; Lu et al. 2013; Shields-Zhou \& Zhu, 2013; Chen et al. 2015).

However, many questions remain unanswered. In particular, taphonomic or facies biases and poor age constraints, both local and global, hamper direct interpretation of these Chinese palaeobiological and geochemical data. In order to use these archives to their best advantage, South China has been a target area of numerous multidisciplinary research programmes in this field. Following previous thematic issues on the NPT of South China published by Palaeogeography Palaeoclimatology Palaeoecology, Acta Palaeontologica Sinica, Precambrian Research and Bulletin of Geosciences (Zhu et al. 2007; Zhu, 2010; Fatka et al. 2012; Shields-Zhou \& Zhu, 2013; Maletz et al. 2014), this thematic issue of Geological Magazine presents the most recent advances in the field based on studies of material from China, mostly South China. These studies cover a range of aspects including chronostratigraphy, geochronology, palaeobiology and sedimentary geochemistry. We hope that these new contributions will help to deepen current understanding about the NPT of the Earth-life system. New insights and the significant details from these contributions are outlined below.

\section{Advances in Ediacaran - early Cambrian chronostratigraphy and geochronology}

The absence of a high-resolution Ediacaran - early Cambrian global chronostratigraphic framework was hitherto a major reason for controversies surrounding models of the evolution of life and environment during the NPT. Since biostratigraphy is of limited usefulness for intra-basinal and inter-basinal stratigraphic correlation between Ediacaran - lower Cambrian 


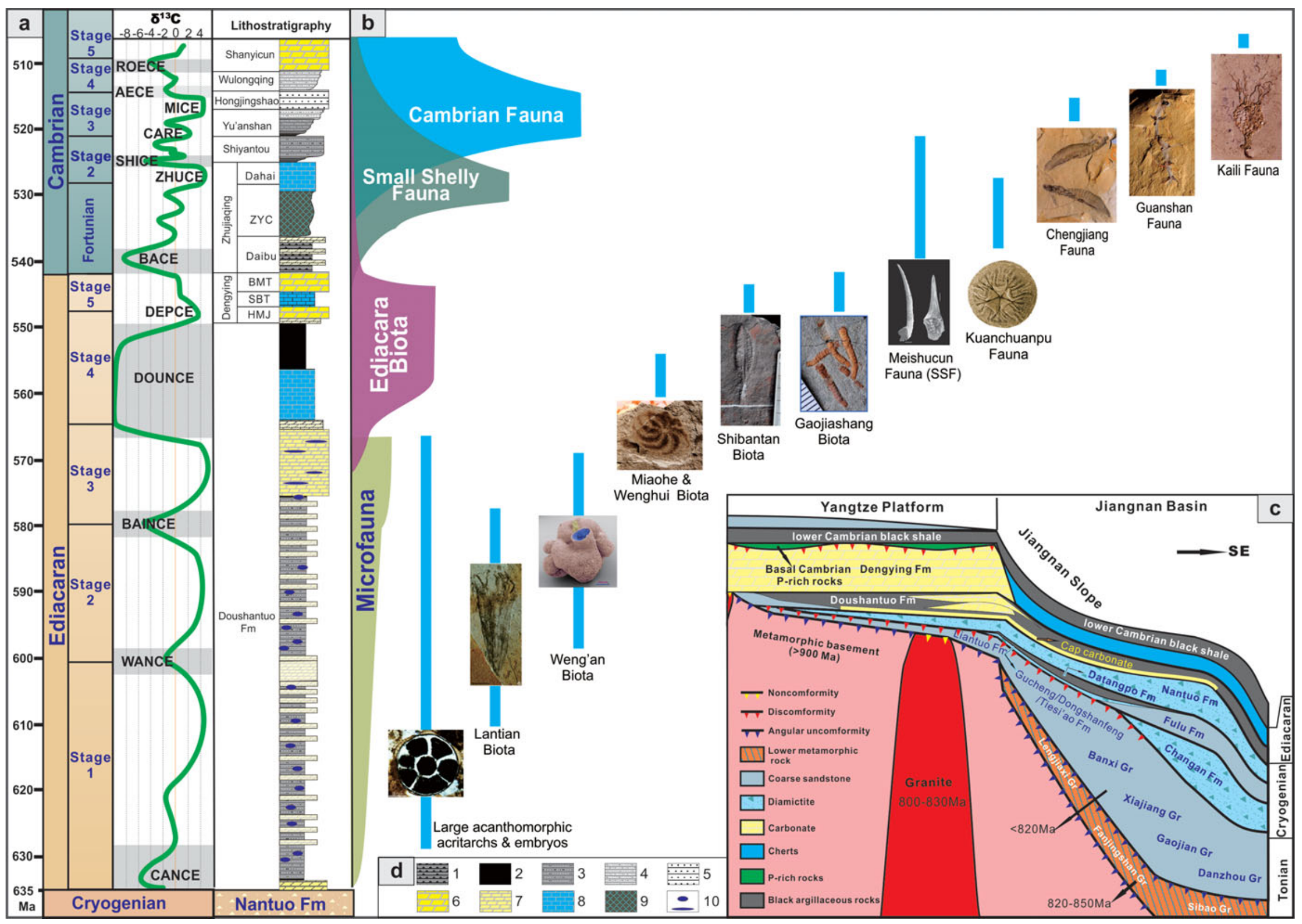




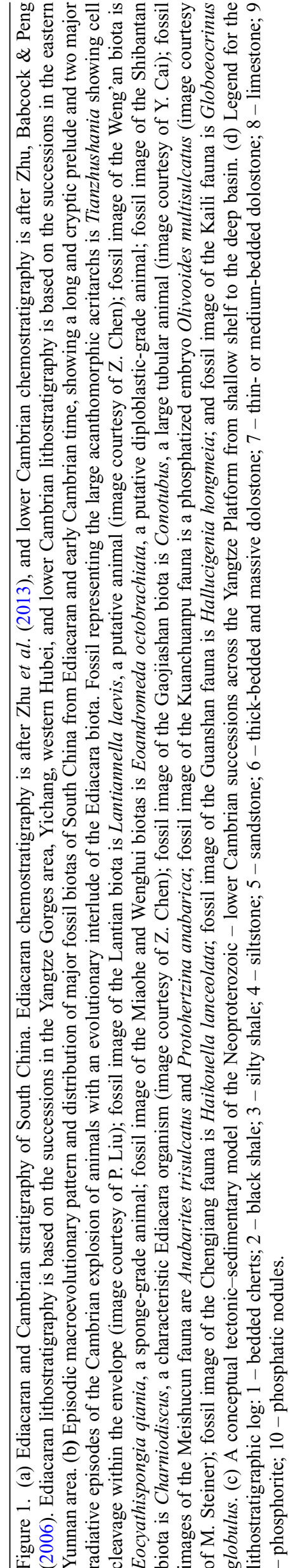

successions, owing mainly to low species diversity, taxonomic uncertainty, and the sporadic and endemic palaeogeographic distribution of the fossils, it is generally agreed that high-resolution Ediacaran - early Cambrian chronostratigraphy requires integration of chemo- and biostratigraphic data with precise age constraints. The well-exposed and fossiliferous Ediacaran successions in the Yangtze Gorges area and lower Cambrian successions in the eastern Yunnan area of South China have long shown great potential for establishing such a high-resolution global chronostratigraphy. In recent decades, a generalized Ediacaran - early Cambrian chronostratigraphic model has been established (Fig. 1). However, the implications of the model for intra-basinal and inter-basinal correlations are still problematic, owing largely to the absence of age constraints for some prominent carbon isotopic anomalies, as well as for the first and last appearances of potential biostratigraphic index fossils, thus limiting attempts to calibrate bio- and geo-events during this critical transition.

In this special issue, Zhou et al. (2017: this issue) report a SIMS zircon $\mathrm{U}-\mathrm{Pb}$ age of $609 \pm 5 \mathrm{Ma}$ for a tuffaceous bed immediately above the upper phosphorite unit of the lower Ediacaran Doushantuo Formation in the northern Yichang area, South China. Integrated litho-, bio- and chemostratigraphic correlations suggest that this unit is correlative with the upper Doushantuo phosphorite unit in the Weng'an area of central Guizhou. Therefore, these new age constraints indicate that the Weng'an biota could be as old as $609 \pm 5 \mathrm{Ma}$.

Yang et al. (2017a: this issue) report intriguing SIMS zircon $\mathrm{Pb}-\mathrm{Pb}$ ages of $553.6 \pm 2.7 \mathrm{Ma}$ and $546.3 \pm 2.7 \mathrm{Ma}$ from ash beds in the middle of the upper Ediacaran Dengying Formation of eastern Yunnan, which are comparable to the ID-TIMS zircon U- $\mathrm{Pb}$ age of $550.55 \pm 0.75 \mathrm{Ma}$ from an ash bed at the base of the Dengying Formation in the Yangtze Gorges area. These new dates imply that the base of the Dengying Formation is diachronous, thus requiring further work to resolve the complex transition between the Doushantuo and Dengying formations in different facies over the Yangtze Platform. The new dates from the middle Dengying Formation also suggest that the Shibantan Ediacara fossil assemblage is younger than the White Sea Assemblage and temporally overlaps with the Nama Assemblage.

Since ratification of the Cambrian GSSP in Newfoundland, defining the base of the Cambrian System on most continents outside the stratotype section has been a challenging task because of facies controls on occurrences of the index trace fossil Treptichnus pedum, as well as the absence of age or isotope constraints at the stratotype section. Therefore, other chronostratigraphic markers are badly needed. The Asteridium-Heliosphaeridium-Comasphaeridium (AHC) acritarch assemblage was considered as a potential biostratigraphic marker for the boundary interval. To test its validity, Ahn \& Zhu (2017: this 
issue) present new data on the stratigraphic range of the AHC acritarch assemblage, and its spatial and temporal relationships to other bio- and chemostratigraphic information from the Yanjiahe Formation, Yangtze Gorges area, South China. The result indicates that the AHC assemblage correlates temporally with the Anabarites trisulcatus-Protohertzina anabarica (small shelly fossils) Assemblage Zone, and correlates spatially with the large negative carbon isotope anomaly at the basal Cambrian (BACE). This suggests that the AHC acritarch assemblage can be used as an additional and important chronological reference for global correlation of the Cambrian base.

Whereas the Ediacaran-Cambrian transition witnessed the rapid diversification of the Cambrian evolutionary fauna, the Cambrian-Ordovician transition records the further radiation of the Cambrian evolutionary fauna into the Palaeozoic evolutionary fauna. In order to accomplish a detailed chronostratigraphy for the Cambrian-Ordovician transition, Li et al. (2017: this issue) report a high-resolution $\mathrm{C}$-isotopic profile of the Wa'ergang section, western Hunan, South China. The Wa'ergang section has been proposed as a potential GSSP for the base of Cambrian Stage 10, the uppermost stage of the Cambrian System, and so these new data provide a chemostratigraphic reference point for global correlation of the Cambrian-Ordovician transition. Additionally, Guo et al. (2017: this issue) report high-resolution $\delta^{13} \mathrm{C}_{\text {carb }}$ data for Ediacaran-Cambrian successions in the Keping area of the Tarim Basin, testing the validity of the chemostratigraphy for inter-basinal correlations.

\section{New palaeobiological information about the early evolution of animals}

The upper Ediacaran Dengying Formation of South China is characterized by a thick succession of carbonate rocks, predominantly dolostone, representing deposition in highly alkaline, seemingly barren shallow seas. However, abundant typical Ediacara fossils (the Shibantan biota) have recently been discovered in the dark grey limestone interval of the middle Dengying Formation in the Yangtze Gorges area. Unlike their preservation usually in siliciclastic rocks, the Shibantan fossils preserved in limestone provide fresh insights into the anatomy and the mode of life of Ediacara fossils. In this issue, Shen et al. (2017: this issue) describe a new Ediacara fossil, Curviacus ediacaranus gen. et sp. nov., from the Shibantan biota. C. ediacaranus exhibits a modular body construction consisting of serially arranged and crescent-shaped chambers, which is broadly similar to the co-occurring Yangtziramulus zhangii and other Ediacara modular fossils, such as Palaeopascichnus, providing new information about the diversity of the late Ediacaran modular organisms.

Chambered structures are also very common in Dengying dolostone and are similar to older, Tonian- age structures that were proposed to be fossils of sponges or sponge-grade organisms. Through detailed petrographic analyses and 3-D representations of these chambered structures within the Dengying dolostone, Luo, Pan \& Reitner (2017: this issue) argue that the structures result from microbial activities. This interpretation is consistent with the widespread occurrence in the Dengying dolostones of microbiolites and stromatolites, reminiscent of the microbe-dominated ecosystems of the Precambrian. The distinct microbially induced sedimentary structures (MISS) reported by Liu \& Zhang (2017: this issue) from the shelly fossil-bearing phosphorite of the Zhujiaqing Formation in eastern Yunnan suggest that this microbially dominated ecosystem may have lasted into earliest Cambrian time, persisting until the arrival of metazoan-dominated ecosystems after $520 \mathrm{Ma}$. Furthermore, a continuous evolutionary transition from late Precambrian to Cambrian times is supported by a multi-layered tubular microfossil Feiyanella manica gen. et sp. nov. from the lowest Cambrian Kuanchuanpu Formation, southern Shaanxi, South China. As reported by Han et al. (2017: this issue), F. manica shows profound similarities in morphology and reproduction to the characteristically late Ediacaran cloudinids (Cloudina and Conotubus).

During the past decades, more than 20 metazoan phyla or clades including primitive vertebrates have been discovered from the Cambrian fossil Lagerstätten of South China, particularly from the Chengjiang, Guanshan and Kaili faunas, providing invaluable information to improve our understanding of the early evolution of animals. Ongoing excavations continually reveal new fossil material discoveries. Three articles in this special issue report such new material. First, Zeng et al. (2017: this issue) describe extraordinarily well-preserved appendages of a trilobite species, Hongshiyanaspis yiliangensis (Zhang \& Lin in Zhang et al. 1980), from the Xiazhuang fossil assemblage within the Hongjingshao Formation (Cambrian Stage 3) near Kunming, Yunnan. This is the seventh trilobite species with complete appendages to be described and reconstructed in the world, and only the second one in China after Eoredlichia intermedia from the Chengjiang Lagerstätte. The new data support the mandibulate affinities of trilobites. Another new report is of a crown group fossil priapulid worm, Xiaoheiqingella sp., from the Cambrian Guanshan Lagerstätte (Cambrian Stage 4) near Kunming, Yunnan (Hu et al. 2017: this issue). The new discovery represents the third occurrence of the crown group fossil priapulids after the Cambrian Chengjiang Lagerstätte and the Pennsylvanian Mazon Creek Lagerstätte. The third new fossil report is by Yang et al. (2017b: this issue), who describe a new vauxiid sponge (Vauxiidae, Verongida), Angulosuspongia sinensis gen. et sp. nov., from the Kaili Formation (Cambrian Stage 5), Jianhe, Guizhou. This is the first discovery of vauxiid fossils reported from outside Laurentia, providing additional 
information towards a better understanding of early demosponge evolution.

\section{Geochemical constraints on the evolution of redox conditions and seawater chemistry}

Increasing evidence suggests that the rise of animals and their subsequent rapid diversification were directly linked to increased oxygenation of the atmosphere and ocean during the NPT (Och \& Shields-Zhou, 2012). However, the exact timing and mechanism of this oxygenation event, and how it links to the early evolution of animals, remain elusive. Recent multi-proxy geochemical studies from South China have indicated a stepwise increase in oxygenation during Ediacaran and early Cambrian times, and that modern-like oxygen levels were reached for the first time in Earth history at $\sim 521 \mathrm{Ma}$, coinciding with the radiation of animals seen in fossil records from South China (Chen et al. 2015). Meanwhile, other studies have proposed a more dynamic history of redox evolution during Ediacaran and early Cambrian times, suggesting that spatio-temporal heterogeneity of redox conditions may have exerted a strong impact on the early evolution of animals (e.g. Jin et al. 2016; Och et al. 2016; Sahoo et al. 2016). Furthermore, statistical analyses of global iron-speciation data suggest only limited oxygenation through the Ediacaran and Cambrian periods (Sperling et al. 2015). These inconsistent results may have been caused by discrepancies among the different geochemical proxies, spatiotemporal heterogeneity of depositional environments and poor stratigraphic constraints on some of the studied successions, thus requiring more surgical investigations.

In this issue, Wei et al. (2017: this issue) focus on redox evolution through a lower Cambrian succession (northwestern Guizhou), which was deposited on the shelf margin of the Yangtze Platform. Through analyses of nitrogen and sulphur isotopes in combination with trace elements (Mo and $\mathrm{U}$ ) based on the drill core material, they conclude that seawater along the Yangtze shelf margin was: (1) anoxic and ferruginous with low sulphate concentration (relatively deep chemocline) during the Cambrian Fortunian and early Age 2; (2) anoxic and sulphidic (shallow chemocline and anoxic photic zone) during the late Cambrian Age 2 and early Age 3; and (3) anoxic and ferruginous during the middle and late Cambrian Age 3. The results also suggest that redox evolution on the Yangtze shelf margin was probably controlled by changing biological activity through feedbacks on the local marine environment.

In contrast to the lower Cambrian succession in the outer shelf environment, Jin et al. (2017: this issue) focused their studies on a lower Cambrian succession at the Wangjiaping section (near Yichang, western Hubei) from an inner shelf environment (in the paper, the authors consider it to represent an outer shelf setting). The high-resolution $\mathrm{Fe}-\mathrm{C}-\mathrm{S}-\mathrm{Al}-\mathrm{Ti}$ geochemical data document a redox transition from dominantly eu- xinic to ferruginous conditions with locally high sulphate availability during Cambrian Stage 3. Furthermore, relatively lower $\delta^{34} \mathrm{~S}_{\mathrm{py}}$ and lower total organic carbon (TOC) values, and higher positive correlation between TOC and $\mathrm{Fe}_{\mathrm{py}} / \mathrm{Fe}_{\mathrm{HR}}$ than deeper water successions reported previously suggested that euxinic conditions at Wangjiaping were in response to increasing marine productivity and organic matter-sinking fluxes. These data further indicate that spatial heterogeneity of redox conditions in the Yangtze shelves played an important role in the distribution of early animals.

In addition to redox evolution, Feng et al. (2017: this issue) present major element data for the Fulu iron formation (IF) within Neoproterozoic glacial successions of South China. The data suggest that the iron source for the Fulu IF comprised a binary mixture between a hydrothermal source and detrital loads, although high-temperature hydrothermal input may also have contributed some iron to the IF. The data also indicate that the Fulu IF precipitated across an iron chemocline that separated a weakly oxic surface ocean from an oxygen-depleted deep ocean during the Neoproterozoic glaciation. Furthermore, the paper by Zhu \& Jiang (2017: this issue) reports rare earth element (REE) data for the Ediacaran Doushantuo phosphorite, which contains the well-preserved phosphatized microfossils known as the Weng' an biota at Weng'an, central Guizhou. The results indicate a complex diagenetic history of the phosphatic grains, and suggest that the phosphorite formed under oxic bottom-water conditions with the involvement of hydrothermal fluids, providing new insight into the Ediacaran phosphorites and phosphatic fossils.

Acknowledgements. Papers in this special issue are mostly by members of the National 973 programme "From snowball Earth to the Cambrian explosion: Coevolution of life and environment around 600 myr ago" funded by the Ministry of Science and Technology of China (grant no. 2013CB835000). We particularly wish to thank the all the reviewers and our colleagues, without whose help this special issue would not be possible.

\section{References}

AhN, S. Y. \& ZHU, M. 2017. Lowermost Cambrian acritarchs from the Yanjiahe Formation, South China: implication for defining the base of the Cambrian in the Yangtze Platform. Geological Magazine 154, 1217-31.

Chen, X., Ling, H.-F., Vance, D., Shields-Zhou, G., Zhu, M., Poulton, S. W., Och, L. M., Jiang, S.-Y., LI, D., Cremonese, L. \& Archer, C. 2015. Rise to modern levels of ocean oxygenation coincided with the Cambrian radiation of animals. Nature Communications 6, 7142.

Fatka, V., Steiner, M., Weber, B. \& Zhu, M. 2012. The Precambrian-Cambrian biosphere (r)evolution: insights from Chinese microcontinents. Bulletin of Geosciences 87 (1), 67-70.

Feng, L., Huang, J., Lu, D. \& Zhang, Q. 2017. Major and trace element geochemistry of the Neoproterozoic 
syn-glacial Fulu iron formation, South China. Geological Magazine 154, 1371-80.

Guo, Q., Deng, Y., Hu, J. \& WANG, L. 2017. Carbonate carbon isotope evolution of seawater across the EdiacaranCambrian transition: evidence from the Keping area, Tarim Basin, NW China. Geological Magazine 154, 1244-56.

Han, J., Cai, Y., Schiffbauer, J. D., Hua, H., Wang, X., Yang, X., Uesugi, K., Komiya, T. \& Sun, J. 2017. A Cloudina-like fossil with evidence of asexual reproduction from the lowest Cambrian, South China. Geological Magazine 154, 1294-1305.

Hu, S., Zhu, M., Zhao, F. \& Steiner, M. 2017. A crown group priapulid from the early Cambrian Guanshan Lagerstätte. Geological Magazine 154, 1329-33.

Jin, C., Li, C., Algeo, T. J., Cheng, M., Lei, L., Zhang, Z. \& SHI, W. 2017. Evidence for marine redox control on spatial colonization of early animals during Cambrian Age 3 (c. 521-514 Ma) in South China. Geological Magazine 154, 1360-70.

Jin, C., Li, C., Algeo, T. J., Planavsky, N. J., Cui, H., Yang, X., Zhao, Y., Zhang, X., XIE, S. 2016. A highly redox-heterogeneous ocean in South China during the early Cambrian ( 529-514 Ma): implications for biota-environment co-evolution. Earth and Planetary Science Letters 441, 38-51.

Li, C., Love, G. D., Lyons, T. W., Fike, D. A., Sessions, A. L. \& CHU, X. 2010. A stratified redox model for the Ediacaran ocean. Science 328, 80-3.

Li, D., Zhang, X., Chen, K., Zhang, G., Chen, X., Huang, W., Peng, S. \& Shen, Y. 2017. High-resolution Cisotope chemostratigraphy of the uppermost Cambrian stage (Stage 10) in South China: implications for defining the base of Stage 10 and palaeoenvironmental change. Geological Magazine 154, 1232-43.

LiU, W. \& Zhang, X. 2017. Possible biogenic structures from the Lower Cambrian strata in Yunnan Province, South China. Geological Magazine 154, 1285-93.

Lu, M., Zhu, M., Zhang, J., Shields, G. A., Li, G., ZhaO, F., ZhaO, X. \& ZhaO, M. 2013. The DOUNCE event at the top of the Ediacaran Doushantuo Formation of South China: wide stratigraphic occurrence and non-diagenetic origin. Precambrian Research 225, 86-109.

Luo, C., Pan, B. \& Reitner, J. 2017. Chambered structures from the Ediacaran Dengying Formation, Huize County, Yunnan Province: analogues of the problematic Cryogenian 'proto-poriferans'. Geological Magazine 154, 1269-84.

Maletz, J., Steiner, M., Weber, B. \& Zhu, M. 2014. The Cambrian bioradiation. Palaeogeography, Palaeoclimatology, Palaeoecology 398, 1-186.

Och, L. M., Cremonese, L., Shields-Zhou, G. A., Poulton, S. W., Struck, U., Ling, H., Li, D., Chen, X., Manning, C., Thirlwall, M. \& Strauss, H. 2016. Palaeoceanographic controls on spatial redox distribution over the Yangtze Platform during the Ediacaran-Cambrian transition. Sedimentology 63, 378-410.

Och, L. M. \& Shields-Zhou, G. A. 2012. The Neoproterozoic oxygenation event: environmental perturbations and biogeochemical cycling. Earth-Science Reviews 110, 26-57.

Sahoo, S., Planavsky, N., Jiang, G., Kendall, B., Owens, J., Wang, X., Shi, X., Anbar, A. \& Lyons, T. 2016. Oceanic oxygenation events in the anoxic Ediacaran ocean. Geobiology 14 (5), 457-68.
Sahoo, S. K., Planavsky, N. J., Kendall, B., Wang, X., Shi, X., Scott, C., Anbar, A. D., Lyons, T. W. \& JIANG, G. 2012. Ocean oxygenation in the wake of the Marinoan glaciation. Nature 489, 546-9.

Shen, B., Xiao, S., Zhou, C., Dong, L., Chang, J. \& Chen, Z. 2017. A new modular palaeopascichnid fossil Curviacus ediacaranus new genus and species from the Ediacaran Dengying Formation in the Yangtze Gorges area of South China. Geological Magazine 154, 1257-68.

Shields-Zhou, G. \& ZHU, M. 2013. Biogeochemical changes across the Ediacaran-Cambrian transition in South China. Precambrian Research 225, 1-6.

Sperling, E. A., Wolock, C. J., Morgan, A. S., Gill, B. C., Marcus, K., Halverson, G. P., Macdonald, F. A., Knoll, A. H. \& Johnston, D. T. 2015. Statistical analysis of iron geochemical data suggests limited Late Proterozoic oxygenation. Nature 523, 451-4.

Wei, G.-Y., Ling, H.-F., Li, D., Wei, W., Wang, D., Chen, X., ZHU, X.-K., Zhang, F.-F. \& YAN, B. 2017. Marine redox evolution in the early Cambrian Yangtze shelf margin area: evidence from trace elements, nitrogen and sulphur isotopes. Geological Magazine 154, 1344-59.

YANG, C., LI, X.-H., ZhU, M. \& Condon, D. J. 2017 a. SIMS U-Pb zircon geochronological constraints on upper Ediacaran stratigraphic correlations, South China. Geological Magazine 154, 1202-16.

Yang, X., ZhaO, Y., Babcock, L. E. \& Peng, J. 2017b. A new vauxiid sponge from the Kaili Biota (Cambrian Stage 5), Guizhou, South China. Geological Magazine 154, 1334-43.

Zhang, W. T., Lu, Y. H., Zhu, Z. L., Qian, Y. Y., Lin, H. L., Zhou, Z. Y., Zhang, S. G. \& Yuan, J. L. 1980. Cambrian Trilobite Faunas of Southwestern China. Beijing: Science Press, 497 pp. (in Chinese with English summary).

Zeng, H., ZhaO, F., Yin, Z. \& ZHU, M. 2017. Appendages of an early Cambrian metadoxidid trilobite from Yunnan, SW China support mandibulate affinities of trilobites and artiopods. Geological Magazine 154, 1306-28.

Zhou, C., Li, X.-H., Xiao, S., Lan, Z., Ouyang, Q., Guan, C. \& CHEN, Z. 2017. A new SIMS zircon U-Pb date from the Ediacaran Doushantuo Formation: age constraint on the Weng'an biota. Geological Magazine 154, $1193-1201$.

ZHU, M.-Y. 2010. The origin and Cambrian explosion of animals: fossil evidence from China. Acta Palaeontologica Sinica 49, 325-35.

Zhu, M. Y., BABCock, L. E. \& Peng, S. C. 2006. Advances in Cambrian stratigraphy and paleontology: integrating correlation techniques, palaeobiology, taphonomy and paleoenvironmental reconstruction. Palaeoworld 15, 217-22.

ZHU, B. \& JIANG, S.-Y. 2017. A LA-ICP-MS analysis of rare earth elements on phosphatic grains of the Ediacaran Doushantuo phosphorite at Weng'an, South China: implication for depositional conditions and diagenetic processes. Geological Magazine 154, 1381-97.

Zhu, M., Lu, M., Zhang, J., Zhao, F., Li, G., ZhaO, X. \& ZHAO, M. 2013. Carbon isotope chemostratigraphy and sedimentary facies evolution of the Ediacaran Doushantuo Formation in western Hubei, South China. Precambrian Research 225, 7-28.

Zhu, M., Strauss, H. \& Shields, G. A. 2007. From Snowball Earth to the Cambrian bioradiation: calibration of Ediacaran-Cambrian Earth history in South China. Palaeogeography, Palaeoclimatology, Palaeoecology 54 (1-2), 1-6. 